\title{
UPAYA PENINGKATAN GERAK DASAR KAYANG DENGAN ALAT BANTU BOLA, BOX DAN BANTUAN TEMAN
}

\author{
Ramando Gentana, Rahmat Hermawan, Ade Jubaedi \\ Fakultas Keguruan dan Ilmu Pendidikan \\ Universitas Lampung \\ Email: genta9255@gmail.com
}

\begin{abstract}
This study aims to improve and improve the learning process, especially in the basic movements of kayang. The results of the analysis showed that in the first cycle with the help of a ball aid, an increase in the average value of 62.33 was obtained by calculating the effectivity level of $32.94 \%$, which meant that the action had not been effective. In the second cycle with a tool in the form of a box obtained an increase with an average value of 70.22 with the calculation of the effectivity level of $49.76 \%$ that means the action has not been effective. In the third cycle with the use of peer assistance, an increase in the average value of 82.33 was obtained by calculating the effectivity level of $75.59 \%$. The conclusion of the analysis results that each cycle has increased by more than 50\%, which means that the action has been effective with tools such as balls, boxes and friend assistance.
\end{abstract}

Keywords: balls, boxes, friend assistance, kayang

\begin{abstract}
ABSTRAK
Penelitian ini bertujuan untuk meningkatkan dan memperbaiki proses pembelajaran khususnya dalam gerak dasar kayang. Hasil analisis menunjukan pada siklus pertama dengan bantuan alat bantu berupa bola diperoleh peningkatan rata-rata nilai sebesar 62,33 dengan perhitungan tingkat efekivitas 32,94 \% itu berarti tindakan belum efektif. Pada siklus kedua dengan alat bantu berupa box diperoleh peningkatan dengan rata-rata nilai sebesar 70,22 dengan perhitungan tingkat efekivitas $49,76 \%$ itu berarti tindakan belum efektif. Pada siklus ketiga dengan penggunaan bantuan teman diperoleh peningkatan rata-rata nilai sebesar 82,33 dengan perhitungan tingkat efekivitas $75,59 \%$. Kesimpulan dari hasil analisis tersebut bahwa setiap siklus telah meningkat lebih dari $50 \%$ itu artinya tindakan telah efektif dengan alat bantu berupa bola, box dan bantuan teman.
\end{abstract}

Kata Kunci: bantuan teman, bola, box, kayang

\section{PENDAHULUAN}

Pendidikan Jasmani Olahraga dan

Kesehatan merupakan bagian dari pendi-

dikan secara keseluruhan, bertujuan untuk

mengembangkan aspek kebugaran jasma-

ni, keterampilan gerak, keterampilan berpikir kritis, keterampilan sosial, penalaran, stabilitas emosional, tindakan moral, aspek pola hidup sehat dan pengenalan lingkung-an bersih melalui aktivitas jasmani, olah-raga dan kesehatan terpilih yang diren-canakan secara 
sistematis dalam rangka mencapai tujuan pendidikan nasional.

Menurut Victor G. Simanjuntak (2008: 13) bahwa: "Pendidikan Jasmani dan Kesehatan adalah mata pelajaran yang merupakan bagian dari pendidikan kesehatan yang dalam proses pembelajarannya mengutamakan aktivitas jasmani dan kebiasaan hidup sehat menuju pada partumbuhan jasmani, mental, sosial, dan emosional yang selaras serasi dan seimbang”. Pendidikan jasmani olahraga dan kesehatan merupakan media untuk mendorong pertumbuhan fisik, perkembangan psikis, keterampilan motorik pengetahuan dan penalaran, penghayatan nilai-nilai (sikap mental, emosional, sportifitas, spiritual, sosial), serta pembiasaan pola hidup sehat yang bermuara untuk merangsang pertumbuhan dan perkembangan kualitas fisik dan psikis yang seimbang.

Ngalim Purwanto (2002: 14) menyatakan bahwa, "Melalui pendidikan jasmani anak didik akan memperoleh berbagai pengalaman terutama yang sangat erat kaitannya dengan kesan pribadi yang menyenangkan, berbagai ungkapan yang kreatif, inofatif, keterampilan gerak, kebugaran jasmani, membiasakan hidup sehat, memiliki pengetahuan dan pemahaman terhadap sesama manusia." Dalam proses pembelajaran pendidikan jasmani dan kesehatan guru diharapkan mengajarkan berbagai keterampilan gerak dasar, teknik dan strategi permainan olahraga, internalisasi nilai-nilai (sportivitas, jujur, kerjasama, disiplin, bertanggung jawab) dan pembiasaan pola hidup sehat, yang dalam pelaksanaanya bukan melalui pengajaran konvensional di dalam kelas yang bersifat kajian teoritis, namun melibatkan unsur fisik, mental intelektual, emosi dan sosial, sikap murid terhadap nilai-nilai biasanya sangat dipengaruhi oleh persepsinya tentang tingkah laku gurunya, Sarwoto (1994: 4) berpendapat "Guru harus dapat memberikan penafsiran yang tepat mengenai jenis dan fungsi tujuan yang akan dicapai." Aktivitas yang diberikan dalam pengajaran harus dapat sentuhan didaktik metodik, sehingga 
aktivitas yang dilakukan dapat mencapai tujuan pengajaran.

Menurut Sukadiyanto (1997: 70) bahwa "kemampuan gerak adalah suatu kemampuan seseorang dalam menampilkan ketrampilan gerak yang lebih luas serta diperjelas bahwa kemampuan motorik suatu kemampuan umum yang berkaitan dengan penampilan berbagai keterampilan atau tugas gerak". Dengan demikian bisa ditarik kesimpulan bahwa kemampuan motorik adalah suatu kemampuan yang diperoleh dari keterampilan gerak umum, yang menjadi dasar untuk meningkatkan pertumbuhan dan perkembangan keterampilan gerak. Seseorang yang memiliki tingkat kemampuan motorik yang tinggi dapat diartikan bahwa orang tersebut memiliki potensi atau kemampuan untuk melakukan keterampilan gerak yang lebih baik dibandingkan dengan orang yang memiliki kemampuan motorik rendah.

Menurut Schmidt (1991: 40) menjelaskan bahwa pembelajaran gerak adalah " a set of processed associated with prac- tice or experience leading to relatively permanent changes in the capability responding”. Menurut Lutan (1988: 93) bahwa kemampuan motorik kasar adalah kapasitas seseorang yang berkaitan dengan pelaksanaan dan peragaan suatu keterampilan yang relatif melekat setelah masa anak-anak.

Edgar Dale (dalam Sumanto, 1994: 271), menyatakan bahwa hasil belajar seseorang diperoleh mulai dari pengalaman langsung (kongkret) berdasarkan kenyataan yang ada di lingkungan hidupnya, kemudian melalui benda-benda tiruan, dan selanjutnya sampai kepada lambang-lambang verbal (abstrak). Untuk kondisi seperti inilah kehadiran media pembelajaran menjadi sangat signifikan bagi terciptanya proses dan hasil pembelajaran yang optimal. Dalam posisinya ini, media diharapkan dapat merangsang keterlibatan berbagai alat indera atau dimaksimalkan bagi seluruh alat indera pembelajar. Di samping itu, Edgar Dale memberikan solusi untuk memecahkan persoalan 
berdasarkan tingkat keabstrakan pengalaman yang dihadapi pembelajar (peserta didik). Kenyataan ini didukung oleh landasan teori penggunaan media yang dikemukakan oleh Edgar Dale, yaitu teori Kerucut Pengalaman Dale (Dale's Cone of Experience) seperti pada gambar 1.

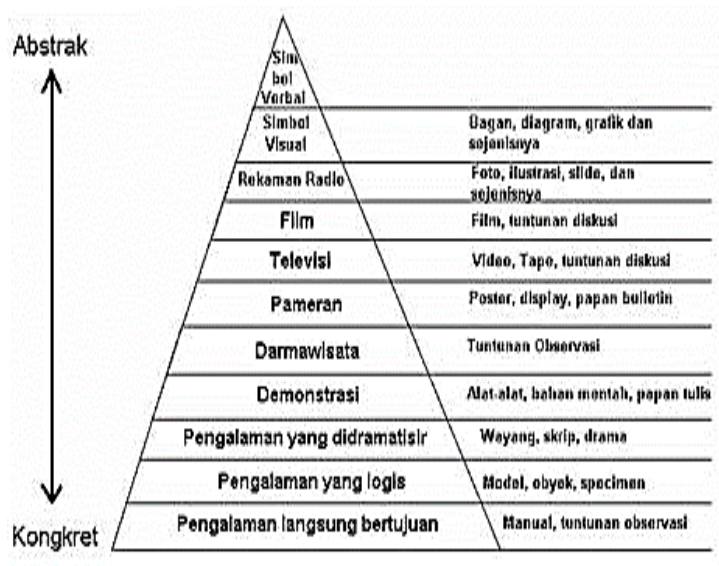

Gambar 1. Kerucut Pengalaman Edgar Dale

Yusuf (1985: 68) menjabarkan, bahwa alat bantu adalah alat yang digunakan pengajar dalam menyampaikan materi, dengan adanya alat peraga maka bahan ajar atau materi akan lebih mudah dimengerti, oleh peserta didik. Alat peraga adalah alat 9 yang dapat memperdengarkan atau dapat memperagakan bahanbahan tersebut, sehingga murid-murid dapat menyaksikan langsung, mengamat- amati dengan cermat, memegang atau merasakan bahan-bahan peragaan pelajar itu.

Senam adalah salah satu cabang olahraga yang masuk pada dalam kelompok pelajaran aktifitas senam, yang mana pada kelompok ini pada umumnya menjadi aktivitas yang digemari oleh anak-anak pada usia sekolah menengah. Kelompok permainan dan olahraga ini terdiri atas berbagai macam permainan, antara lain: senam lantai, senam irama, permainan, eksplorasi gerak, keterampilan lokomotor, non-lokomotor, dan manipulatif, dan aktivitas lainnya.

Menurut Imam Hidayat (dalam Agus Mahendra 2001: 1) Senam merupakan suatu cabang olahraga yang melibatkan performa gerakan yang membutuhkan kekuatan, kecepatan dan keserasian gerakan fisik yang teratur. Gerakan-gerakan senam sangat sesuai untuk mengisi program pendidikan jasmani. Gerakannya merangsang perkembangan komponen kebugaran jasmani, seperti kekuatan dan daya tahan otot dari seluruh bagian tubuh. 
Di samping itu, senam juga berpotensi mengembangkan keterampilan gerak dasar, sebagai landasan penting bagi penguasaan keterampilan teknik suatu cabang olahraga.

Senam untuk anak sekolah dasar tentu berbeda sifatnya dengan senam yang dipertandingkan. Di sini senam sematamata sebagai alat untuk mengantar anak mencapai perkembangan secara menyeluruh, mencakup aspek fisik, mental, emosional, dan moral. Gerakan-gerakannya tentu harus disesuaikan dengan kepentingan itu, dan sejauh mungkin dimaksudkan untuk memberikan pengalaman gerak sebanyak-banyaknya bagi anak. Upaya meningkatkan kemampuan siswa SD melakukan kayang harus dilakukan pembelajaran secara sistematis dan teratur. Selain itu, dibutuhkan cara belajar yang tepat, karena kayang merupakan jenis keterampilan yang menuntut skill yang tinggi terutama kelentukan.

Kesulitan yang sering di alami siswa pada gerakan kayang adalah siswa takut melakukan hal ini karena siswa memiliki tingkat kelentukan yang kurang maksimal. Untuk mengatasi kesulitan siswa dalam melakukan kayang, maka perlu diciptakan cara belajar kayang dengan tepat dan sesuai, salah satunya bentuk pembelajaran dengan menggunakan model pembelajaran bantuan Bola, Box dan bantuan teman. Pembelajaran kayang dengan menggunakan model pembelajaran bantuan Bola, Box dan bantuan teman merupakan salah satu cara atau solusi yang ditawarkan untuk mengatasi kesulitan dalam melakukan kayang.

Upaya mencapai tujuan pembelajaran seperti yang tertuang dalam Kurikulum tidaklah mudah, banyak sekali kendalanya. Kurangnya sarana pembelajaran senam merupakan faktor yang dialami sekolah-sekolah termasuk di SD Negeri 01 Balai Murni Jaya. Masih banyak sekolahsekolah yang tidak memperhatikan sarana dan prasarana pembelajaran pendidikan jasmani. Biasanya sarana yang disediakan 
oleh sekolah hanya untuk olahraga permainan, itu pun terkadang tidak ideal.

Untuk mengetahui bagaimana pengaruh penggunaan model pembelajaran bantuan Bola, Box dan bantuan teman terhadap peningkatan hasil belajar kayang, maka perlu di lakukan penelitian dengan judul, "Upaya Peningkatan Gerak Dasar Kayang dengan Bantuan Bola, Box dan Bantuan Teman Pada Siswa SD NEGERI 01 Balai Murni Jaya.”

\section{METODE}

Di dalam penelitian ini Peneliti menggunakan Penelitian Tindakan Kelas (Classroom Action Research) dengan siklus sebanyak tiga siklus subjek penelitian berjumlah 30 siswa, terdiri dari 20 lakilaki dan 10 perempuan. Teknik pengumpulan data menggunakan skala observasi keterampilan gerak dasar Kayang. Penelitian dilakukan di lapangan SD Negeri 01 Balai Murni Jaya.

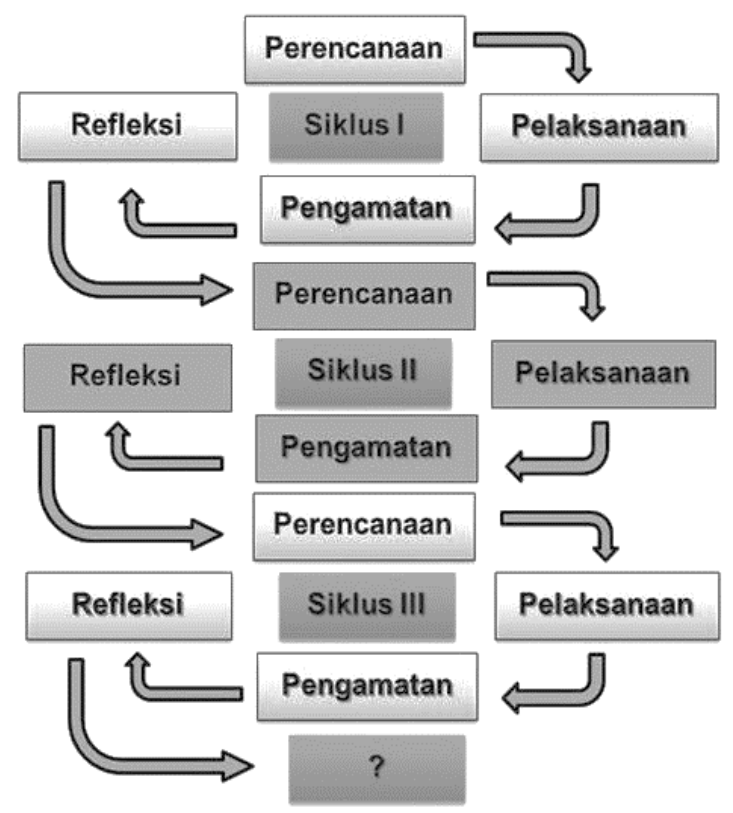

Gambar 2. Desain penelitian tindakan kelas (Arikunto 2010: 137)

Pada penelitian ini penulis melaksanakan penelitian sebanyak tiga siklus. Pada setiap siklusnya diambil data atau penilaian dengan menggunakan instrument penilaian yang telah disiapkan sebelumnya, pertemuan dilaksanakan tes pendemonstrasian kemudian di antara setiap siklusnya penelitian melaksanakan kegiatan tindakan berbeda pada setiap siklus, akan tetapi setiap siklus saling berkaitan, setiap proses penelitian merupakan tindakan lanjutan dari siklus penelitian sebelumnya. Sebelum memasuki pelaksanaan penelitian siswa diberikan tes awal melakukan gerakan kayang tanpa meng- 
gunakan alat bantu dan dinilai dengan menggunakan instrumen penelitian yang telah dipersiapkan sebelumnya.

Penelitian ini dilakukan selama 40 hari sebelum melakukan penelitian, terlebih dahulu siswa melakukan tes awal gerakan kayang dengan menggunakan instrumen penelitian yang telah dipersiapkan, untuk menentukan alat bantu yang akan digunakan pada setiap siklusnya dan urutan alat yang digunakan pada setiap siklusnya. Masing-masing siklus dilakukan tiga kali pertemuan dengan menggunakan alat bantu berbeda-beda. Setiap siklus diberikan penjelasan dan contoh melakukan gerak dasar kayang yang benar, lalu siswa melakukan gerakan yang telah dicontohkan, di akhir pertemuan pada setiap siklus dievaluasi bersama para siswa dan guru penjas, dan di akhir pertemuan pada setiap siklus, siswa dites dengan menggunakan instrumen penilaian kayang yang telah dipersiapkan, lalu data tersebut dihitung dan dianalisis.
Instrumen adalah alat yang digunakan untuk mengukur pelaksanaan PTK (Penelitian Tindakan Kelas) di setiap siklusnya, menurut Freir and Cuning Ham dalam Muhajir (1997: 58) Alat untuk mengukur instrumen dalam PTK dikatakan valid bila tindakan itu memegang aplikasi dan dapat berfungsi untuk memecahkan masalah yang dihadapi. Alat ini berupa indikator dari penilaian (instrumen) gerak dasar kayang dengan menggunakan metode pembelajaran berupa bola, box dan bantuan teman, yaitu (Suryatna, 2001): 1) tahap persiapan, 2) Tahap gerak atau tahap pelaksanaan, dan 3) Akhir gerak.

Setelah data dikumpulkan melalui tindakan setiap siklusnya, selanjutnya data dianalisis melalui tabulasi, persentase dan normatif menggunakan rumus Djarwanto dan Subagyo (2005: 108), sebagai berikut:

$$
\begin{aligned}
& P=\frac{f}{n} \times 100 \% \\
& P=\frac{\text { jumlah siswa yang tuntas }}{\text { jumlah siswa }} \times 100 \%
\end{aligned}
$$

Keterangan:

$\mathrm{P}=$ Persentase keberhasilan

$\mathrm{f} \quad=$ Jumlah yang melakukan benar

$\mathrm{n}$ = Jumlah siswa yang mengikuti tes 
Siswa yang dikatakan tuntas apabila: 1) Ketuntasan belajar telah mencapai nilai $\geq 70$ atau persentase ketercapaian $65 \%$ secara perorangan (KKM SD Negeri 01 Balai Murni Jaya), 2) Ketuntasan belajar klasikal dicapai bila kelas tersebut telah terdapat $85 \%$ siswa yang telah mendapat nilai $\geq 70$.

Penelitian ini dapat dikatakan terjadinya peningkatan hasil belajar siswa jika jumlah siswa yang tuntas belajar pada siklus pertama lebih sedikit dari pada sesudah siklus kedua dan siklus ketiga dari jumlah siswa yang tuntas belajar pada tindakan sisklus dan seterusnya, atau setiap pergantian siklus terjadi persentase peningkatan hasil belajar siswa.

\section{HASIL DAN PEMBAHASAN}

Sebelum melakukan tindakan atau pemberian materi dan perintah untuk melakukan tindakan siklus pertama, terlebih dahulu dilakukan tes awal. Hasil observasi (tes awal) ini sangat berguna untuk menentukan tindakan yang akan dilakukan pada siklus pertama. Dalam penelitian tindakan kelas (PTK) apakah tindakan dapat meningkatkan hasil belajar dan melihat efektivitas pembelajaran yang dicapai dapat dilihat pada pencapaian nilai rerata kelas dan ketuntasan belajar atau hasil penelitian di setiap siklusnya.

\section{Deskripsi Data}

\section{Jenis Kelamin}

Dari jumlah 30 siswa terdiri atas 20 laki-laki dan 10 perempuan.

\section{Usia}

Usia siswa yang diteliti berusia 11 tahun, dengan perincian pada gambar 3, yang menunjukkan bahwa usia di atas 11 tahun lebih dominan dibandingkan usia 10 tahun.

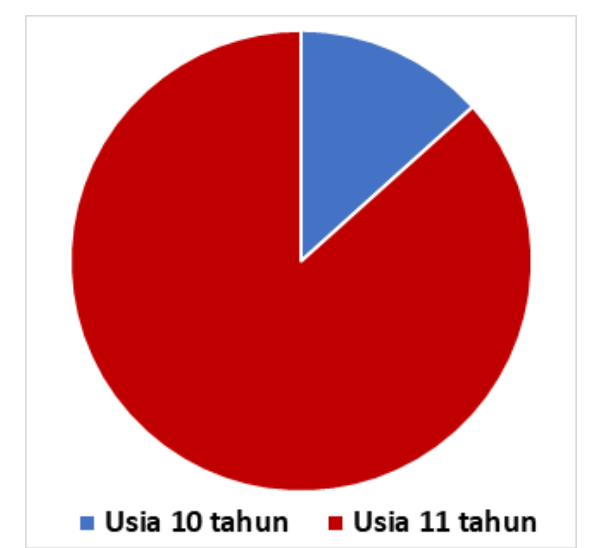

Gambar 3. Diagram Persentase Usia 
Tabel 1. Indikator Penilaian (Instrumen)

\begin{tabular}{|c|c|c|c|c|}
\hline No & Aspek & Indikator & Deskripsi & $\begin{array}{l}\text { Skor } \\
(0 / 1)\end{array}$ \\
\hline \multirow[t]{10}{*}{1} & \multirow[t]{10}{*}{ Persiapan } & \multirow[t]{2}{*}{ Badan } & 1. Berdiri tegak. & \\
\hline & & & 2. Dada dibusungkan. & \\
\hline & & \multirow[t]{2}{*}{ Tungkai } & 1. Kaki dibuka selebar bahu. & \\
\hline & & & 2. Lutut ditekuk $\pm 30^{\circ}$. & \\
\hline & & \multirow[t]{4}{*}{ Lengan } & 1. Kedua tangan di atas kepala. & \\
\hline & & & 2. Kedua siku tangan diluruskan. & \\
\hline & & & 3. Jari-jari tangan dirapatkan. & \\
\hline & & & 4. Telapak tangan menghadap ke depan. & \\
\hline & & \multirow[t]{2}{*}{ Pandangan } & 1. Pandangan lurus ke depan. & \\
\hline & & & 2. Sekitar 4-5 meter. & \\
\hline \multirow[t]{12}{*}{2} & \multirow[t]{12}{*}{ Pelaksanaan } & \multirow[t]{2}{*}{ Badan } & 1. Melentingkan punggung ke belakang. & \\
\hline & & & 2. Sudut punggung $\pm 90^{\circ}$. & \\
\hline & & \multirow[t]{4}{*}{ Tungkai } & 1. Kaki diusahakan tetap lurus. & \\
\hline & & & 2. Pinggul sedikit turun. & \\
\hline & & & 3. Lutut lurus. & \\
\hline & & & 4. Kedua telapak kaki menyentuh matras. & \\
\hline & & \multirow[t]{4}{*}{ Lengan } & 1. Kedua tangan dilengkungkan ke belakang. & \\
\hline & & & 2. Kedua telapak tangan menyentuh matras. & \\
\hline & & & 3. Jari-jari tangan renggang. & \\
\hline & & & 4. Kedua siku tangan tetap lurus. & \\
\hline & & \multirow[t]{2}{*}{ Pandangan } & 1. Pandangan ke atas. & \\
\hline & & & $\begin{array}{l}\text { 2. Setelah kedua telapak tangan menyentuh matras } \\
\text { pandangan ke (lurus) belakang. }\end{array}$ & \\
\hline \multirow[t]{8}{*}{3} & \multirow[t]{8}{*}{ Sikap akhir } & \multirow[t]{3}{*}{ Badan } & 1. Posisi tubuh melengkung ke belakang bagai busur. & \\
\hline & & & 2. Menjaga keseimbangan agar tetap stabil. & \\
\hline & & & 3. Waktu bertahan \pm 3 detik. & \\
\hline & & \multirow[t]{2}{*}{ Tungkai } & 1. Kaki dibuka selebar bahu. & \\
\hline & & & $\begin{array}{l}\text { 2. Lutut ditekuk pada saat tubuh melengkung ke } \\
\text { belakang. }\end{array}$ & \\
\hline & & Lengan & 1. Kedua tangan menjaga keseimbangan. & \\
\hline & & \multirow[t]{2}{*}{ Pandangan } & 1. Pandangan ke atas & \\
\hline & & & $\begin{array}{l}\text { 2. Pandangan lurus ke depan pada saat kembali ke } \\
\text { sikap awal. }\end{array}$ & \\
\hline & & & JUMLAH SKOR & \\
\hline
\end{tabular}


Tabel 2. Deskripsi Hasil Penelitian Tindakan Kelas (PTK) Pembelajaran Gerak Dasar Kayang

\begin{tabular}{|c|c|c|c|c|c|c|c|}
\hline \multirow{2}{*}{ No } & \multirow{2}{*}{ Sikhus } & \multirow{2}{*}{$\overline{\mathbf{x}}$} & \multicolumn{2}{|c|}{ Persentase Nilai } & \multirow{2}{*}{$\begin{array}{c}\text { Jumlah } \\
(\%)\end{array}$} & \multicolumn{2}{|c|}{ T ingkat Efektivitas } \\
\hline & & & $\begin{array}{c}\text { > Ketuntasan } \\
\text { Belajar }\end{array}$ & $\begin{array}{c}<\text { Ketuntasan } \\
\text { Belajar }\end{array}$ & & Ef ektivitas & Keterangan \\
\hline 1 & Tes awal & 46,40 & 6,67 & 93,3 & 100 & 00,00 & -- \\
\hline 2 & Pertama & 62,33 & 20,00 & 80,00 & 100 & 32,20 & Tidak efektif \\
\hline 3 & Kedua & 70,22 & 63,33 & 36,67 & 100 & 51,30 & Belum efektif \\
\hline 4 & Ketiga & 82,33 & 90,00 & 10,00 & 100 & 77,4 & Efektif \\
\hline
\end{tabular}

\section{Gerak Dasar Kayang}

Deskripsi hasil penelitian dimaksudkan untuk memperoleh gambaran tentang penyebaran data yang meliputi nilai tertinggi, nilai terendah, nilai rata-rata serta prosentase dari hasil tes awal dan pada masing-masing siklus yang dapat digambarkan dalam bentuk tabel distribusi maupun diagram batang. Penilaian terhadap keberhasilan studi siswa dapat dilihat dengan pemberian huruf mutu yang didapat siswa.

Dalam penelitian tindakan kelas (PTK) langkah pertama yang dilakukan adalah melakukan tes atau mengambil nilai temuan. Hasil tes temuan ini berguna untuk menentukan tindakan pada siklus pertama dan siklus berikutnya. Dalam pe- nelitian tindakan kelas (PTK) apakah tindakan dapat meningkatkan hasil belajar, dapat dilihat pada pencapaian nilai rerata kelas dan ketuntasan belajar atau dari hasil penelitian di setiap siklusnya (Tabel 3).

Setelah melakukan tinjauan pada putaran pertama atau siklus kesatu, yang diberikan materi gerak dasar kayang dengan bantuan alat bola, kemudian siswa diberikan tes lembar observasi dengan hasil yang tersaji pada tabel 3 .

Setelah melakukan tinjauan pada putaran pertama pada siklus kedua dengan menggunakan alat bantu box, kemudian siswa diberikan tes lembar observasi dengan hasil yang tersaji pada tabel 4 .

Pada siklus ketiga dengan diberikan materi gerak dasar kayang yaitu dengan menggunakan bantuan teman, ke- 
mudian siswa diberikan tes lembar observasi dengan hasil yang tersaji pada tabel 5 .

Tabel 3. Rekapitulasi Analisis Hasil Pembelajaran Gerak Dasar Kayang Siklus I

\begin{tabular}{|c|l|l|r|c|}
\hline No & \multicolumn{1}{|c|}{ Hasil } & \multicolumn{2}{|c|}{ Jumlah } & $\begin{array}{c}\text { Persen } \\
\text { (\%) }\end{array}$ \\
\hline 1 & Rerata & Nilai & 62,33 & 80 \\
\hline 2 & Ketuntasan & Siswa & 6 & 20 \\
\hline
\end{tabular}

Tabel 4. Rekapitulasi Analisis Hasil Pembelajaran Gerak Dasar Kayang Siklus II

\begin{tabular}{|c|l|l|r|c|}
\hline No & \multicolumn{1}{|c|}{ Hasil } & \multicolumn{2}{|c|}{ Jumlah } & \multicolumn{1}{c|}{$\begin{array}{c}\text { Persen } \\
\text { (\%) }\end{array}$} \\
\hline 1 & Rerata & Nilai & 70,2 & 36,67 \\
\hline 2 & Ketuntasan & Siswa & 19 & 63,33 \\
\hline
\end{tabular}

Tabel 5. Rekapitulasi Analisis Hasil Pembelajaran Gerak Dasar Kayang Siklus III

\begin{tabular}{|c|l|l|r|c|}
\hline No & \multicolumn{1}{|c|}{ Hasil } & \multicolumn{2}{|c|}{ Jumlah } & $\begin{array}{c}\text { Persen } \\
(\%)\end{array}$ \\
\hline 1 & Rerata & Nilai & 82,33 & 10 \\
\hline 2 & Ketuntasan & Siswa & 27 & 90 \\
\hline
\end{tabular}

Tabel 6. Hasil Ketuntasan Latihan Gerak Dasar Kayang Meningkat secara Nyata pada Siklus Ketiga

\begin{tabular}{|c|l|r|l|}
\hline No & Tindakan & $\begin{array}{c}\text { Hasil } \\
(\mathbf{\% )}\end{array}$ & Keterangan \\
\hline 1 & Tes Awal & 6,67 & -- \\
\hline 2 & Pertama & 20,00 & Berhasil 6 siswa \\
\hline 3 & Kedua & 63,33 & Berhasil 19 siswa \\
\hline 4 & Ketiga & 90,00 & Berhasil 27 siswa \\
\hline
\end{tabular}

Dari berbagai hasil yang telah dijabarkan melalui beberapa tabel, dapat diketahui bahwa di setiap siklusnya terda- pat peningkatan dari tes temuan siklus satu (1) berhasil 6 siswa dari 30 siswa dengan persentase $20 \%$, kemudian siklus dua (2) berhasil 19 siswa dari 30 siswa dengan persentase $63,33 \%$, kemudian siklus tiga (3) berhasil 27 siswa dari 30 siswa pada siklus ketiga dengan persentase $90 \%$.

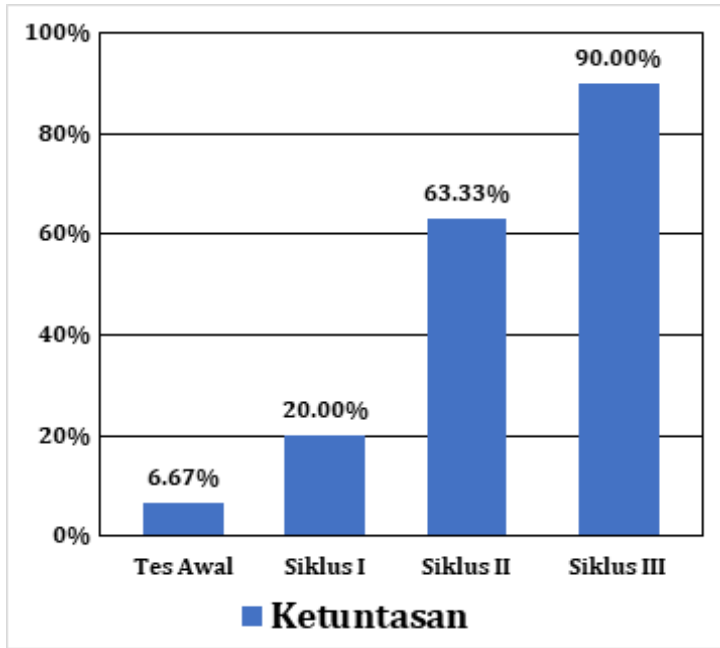

Gambar 4. Presentase Ketuntasan Belajar pada Tes Awal, Siklus I, Siklus II, dan Siklus III.

Untuk mengetahui efektif tidaknya tindakan yang diberikan pada setiap siklus, diperlukan nilai rata-rata kelas. Nilai ratarata kelas pada tes awal akan dibandingkan dengan nilai rata-rata pada setiap siklus. Hasil perhitungan tersebut menunjukkan tingkat efektivitas tindakan yang diberikan. Deskripsi efektivitas pembelajaran pada setiap siklus dijabarkan pada tabel 7. 
Tabel 7. Deskripsi Efektivitas Pembelajaran pada Setiap Siklus

\begin{tabular}{|l|c|c|c|l|}
\hline \multicolumn{1}{|c|}{ Siklus } & $\begin{array}{c}\overline{\mathbf{X}} \text { Tes } \\
\text { Awal }\end{array}$ & $\overline{\mathbf{X}}$ & Efektivitas & Keterangan \\
\hline Pertama & 46,4 & 62,33 & 34,3 & Tidak efektif \\
\hline Kedua & 46,4 & 70,22 & 51,3 & Belum efektif \\
\hline Ketiga & 46,4 & 82,33 & 77,4 & Efektif \\
\hline
\end{tabular}

Berdasarkan hasil evaluasi yang dilakukan, ada peningkatan hasil belajar keterampilan gerak dasar kayang dengan rincian sebagai berikut: 1) Pada siklus pertama dengan penggunaan bantuan alat bantu bola diperoleh peningkatan rata-rata nilai sebesar 62,33 dengan perhitungan tingkat efekivitas $34,3 \%$ itu berarti tindakan belum efektif; 2) Pada siklus kedua dengan penggunaan alat bantu box diperoleh peningkatan dengan rata-rata nilai sebesar 70,22 dengan perhitungan tingkat efektivitas $51,3 \%$ itu berarti tindakan belum efektif. 3) Pada siklus ketiga dengan penggunaan bantuan teman diperoleh peningkatan rata-rata nilai sebesar 82,33 dengan perhitungan tingkat efekivitas 77,4\%. Hasil perhitungan telah meningkat lebih dari 50\% itu artinya tindakan telah efektif.
Berdasarkan data terlampir, persentase kemampuan melakukan gerak dasar Kayang SDN 01 Balai Murni Jaya yang terdiri dari 20 siswa putra dan 10 siswa putri pada tahap pertama atau siklus kesatu siswa melakukan gerak dasar kayang yang benar dengan bantuan bola belum menunjukkan hasil yang diinginkan. Dari 30 subjek kaji tindak dari setiap indikator yang terdapat dalam gerak dasar kayang masih rendah. Berdasarkan Tabel 3, dapat diketahui bahwa siklus pertama perolehan nilai ketuntasan belajar hanya 6 siswa, dan 24 siswa lainnya berada di bawah nilai ketuntasan belajar.

Setelah diberikan tindakan siklus atau putaran kedua dengan alat bantu berupa box, maka dibandingakan hasil siklus kesatu lebih meningkat hasil tes siklus kedua. Berdasarkan Tabel 4, dapat diketahui 
bahwa perolehan nilai ketuntasan belajar hanya 19 siswa, dan 11 siswa lainnya berada di bawah nilai ketuntasan belajar.

Setelah diberikan tindakan siklus terakhir atau putaran ketiga dengan menggunakan bantuan teman, maka dibandingkan hasil siklus kedua lebih meningkat hasil tes siklus ketiga. Berdasarkan Tabel 5, dapat diketahui bahwa perolehan nilai ketuntasan belajar belajar siswa meningkat karena dari 30 siswa, sebanyak 27 siswa mendapat nilai di atas KKM dengan persentase $90 \%$ dan 3 siswa lainnya mendapat nilai di bawah KKM dengan persentase $10 \%$. Hal ini terjadi karena siswa sangat menguasai gerak dasar kayang dengan latihan yang baik, untuk itu peneliti beranggapan ini sudah berhasil dan mendapat nilai yang baik.

Tujuan PTK adalah untuk perbaikan dan peningkatan profesional pendidik dalam menangani proses belajar mengajar. Tujuan ini dapat dicapai dengan melakukan berbagai tindakan alternatif dalam menyelesaikan berbagai persoalan pembela- jaran. Daur ulang dalam penelitian tindakan kelas diawali dengan perencaaan tindakan (planning), penerapan tindakan (action), observasi dan mengevaluasi proses dan hasil tindakan, melakukan refleksi dan seterusnya sampai perbaikan atau peningkatan yang diharapkan tercapai (kriteria keberhasilan). Menurut Arikunto (2010: 61) tujuan PTK adalah untuk meningkatkan mutu proses dan hasil pembelajaran, mengatasi masalah pembelajaran, meningkatkan profesionalisme dan menumbuhkan budaya akademik.

Tujuan Peneliti adalah untuk perbaikan dan peningkatan profesionalitas pendidik dalam menangani proses belajar mengajar. Tujuan ini dapat dicapai dengan melakukan berbagai tindakan alternatif dalam menyelesaikan berbagai persoalan pembelajaran. Dalam PTK bukan hanya peneliti yang merasakan hasil tindakan tetapi bila perlakuan dilakukan pada responden maka responden dapat juga merasakan hasil perlakuan. 
Dari proses penelitian dan hasil pengamatan pada tes siklus pertama menggunakan bantuan bola, ditemukan masih banyak siswa-siswi yang mengalami kesulitan dan kesalahan pada gerak dasar kayang baik dari sikap awal, pelaksaan dan sikap akhir. Posisi badan dan kelenturan siswa yang masih belum terlatih membuat siswa kesulitan dalam melakukan keterampilan gerak dasar kayang sehingga banyak yang terjatuh dan gagal sebelum sikap akhir. Oleh sebab itu, penelitian kembali dilanjutkan kepada siklus kedua dalam proses peningkatan gerak dasar kayang dengan memanfaatkan alat bantu box. Alat ini digunakan agar siswa mampu mempraktikan gerak dasar kayang dengan lebih semangat lagi dan siswa lebih tertarik lagi mengikuti proses pembelajaran memudahkan siswa untuk melakukan pengulangan setiap gerakan. Ini terbukti dengan meningkatnya jumlah siswa yang mendapat nilai lebih baik dibandingkan dengan siklus pertama.
Dari hasil pengamatan pada tes siklus kedua, sebagian siswa masih mengalami kendala pada saat melakukan gerakan dasar kayang sehingga saat melakukan kayang banyak siswa yang tidak melentingkan badan dengan sempurna dan menempatkan tangan dengan tepat.

Dari hasil pengamatan pada tes siklus ketiga, siswa semakin menguasai gerak dasar dengan baik dilihat dari banyaknya siswa yang tuntas dalam melakukan gerak dasar kayang karena siswa telah berulang-ulang mendengar, melihat, dan melakukan gerak dasar kayang seusai arahan yang diajarkan oleh peneliti.

\section{KESIMPULAN}

Berdasarkan analisis dan pembahasan dari penelitian, pada setiap siklus maka dapat disimpulkan hasil penelitian tindakan dengan alat bantu pembelajaran sebagai berikut:

1. Dengan menggunakan media alat bantu bola, siswa dapat mempermudah dalam melakukan gerak dasar kayang 
tetapi belum efektif karena bola tersebut masih sedikit lebih kecil sehingga belum bisa membentuk gerakan kayang siswa.

2. Dengan menggunakan media alat bantu box, beberapa siswa sudah dapat melakukan gerak dasar kayang dengan baik tetapi masih belum bisa efektif sepenuhnya dikarenakan box tersebut masih belum bisa membentuk lentingan badan siswa dari sikap awal hingga akhir.

3. Dengan menggunakan media bantuan teman, ternyata siswa dapat melakukan gerak dasar kayang dengan sangat baik. Karena melalui bantuan teman dapat menopang dan melatih siswa dalam melakukan gerakan dari awal hingga akhir.

\section{Saran}

Berdasarkan kesimpulan di atas dapat diketahui bahwa kegiatan PTK dapat meningkatkan aktivitas dan hasil belajar siswa, maka penulis memberikan saran sebagai berikut:
1. Hendaknya siswa-siswi SD Negeri 01 Balai Murni Jaya meningkatkan kemampuan baik dalam pengetahuan maupun kemampuan motorik, melalui berbagai sumber dan berbagai alat, khususnya pada kemampuan gerak dasar kayang dan pembelajaran keterampilan motorik lain pada umumnya.

2. Penelitian ini dirasakan masih banyak keterbatasannya, oleh karena itu diharapkan adanya tindak lanjut dan penyempurnaan khususnya bagi mahasiswa penjaskes agar dapat terus memperbaiki dan dapat melakukan penelitian selanjutnya.

3. Perlu menambah jumlah tindakan dengan metode atau model pembelajaran yang berbentuk beda dengan penilitian yang dilakukan ini, dengan tujuan untuk memperoleh sejumlah informasi yang berbeda.

\section{DAFTAR PUSTAKA}

Arikunto, Suharsimi. (2010). Prosedur penelitian: suatu pendekatan praktek. Jakarta: PT Rineka Cipta. 
Ary, Budhi Prasetya. (2016). Pengembangan media alat bantu kayang pembelajaran senam lantai. Universitas Negeri Semarang. Journal of Physical Education, Sport, Health and Recreations, 5(3).

Brick, Lynne. (2001). Bugar dengan senam aerobik. Jakarta: PT Raja Grafindo Persada.

Djarwanto, P.S., dan Subagyo, Pangestu. (2005). Statistik induktif. Edisi Kelima. Yogyakarta: BPFE.

Hopkins, David. (1993). A teacher's guide to classroom research. Philadelphia: Open University Press.

Kemmis, S.Mc., Taggart, R. (1992). Penelitian tindakan kelas. Jakarta: Kencana.

Lutan, Rusli. (1988). Belajar ketrampilan motorik, pengantar teori dan metode. Jakarta: Depdikbud Dirjen Dikti PPLPTK.
Mahendra, Agus. (2002). Pembelajaran senam untuk sekolah. Jakarta: Depdiknas.

Muhajir. (1997). Pedoman pelaksanaan penelitian tindakan kelas. Jakarta: Depdikbud Dirjen Dikti.

Purwanto, Ngalim. (2002). Psikologi pendidikan. Bandung: PT. Remaja Rosdakarya.

Schmidt, Richard A. (1991). Motor learning and performance. Illinois: Human Kinetics Books Publisher.Inc.

Simanjuntak, Victor G., Kaswari, dan Eka Supristna. (2008). Pendidikan jasmani dan kesehatan. Jakarta: Dirjen Pendidikan Tinggi Departemen Pendidikan Nasional.

Sukadiyanto. (1997). Penentuan tahap kemampuan motorik anak sekolah dasar. Yogyakarta: FIK UNY. 